\title{
Lipid changes in the brain in phenylketonuria
}

\author{
J. N. CUMINGS, I. K. GRUNDT, AND T. YANAGIHARA \\ Department of Chemical Pathology, Institute of Neurology, \\ The National Hospital, Queen Square, London,
}

Histological changes, particularly those of apparent demyelination, are known to be present in the brains of subjects with phenylketonuria (Poser and van Bogaert, 1959; Crome, Tymms, and Woolf, 1962), and this has been found in association with a loss of cerebrosides (Crome et al., 1962). Recently in a few cases of this condition a disturbance of the fatty acid composition of cerebrosides and sulphatides has been described (Foote, Allen, and Agranoff, 1965; Menkes, 1966).

We have examined the lipid content of the brain in four cases of phenylketonuria, one being the case described by Poser and van Bogaert (1959), and in one case the fatty acid distribution in cerebroside and sulphatide together with the phospholipid plasmalogens have also been determined and the findings that have been obtained are reported here.

\section{MATERIALS AND METHODS}

Portions of four brains have been examined, three from Dr. L. Crome and Dr. M. Erdohazi, aged $1 \frac{1}{4}, 18$, and 29 years, and one from Dr. C. M. Poser, aged 18 years. Three brains had been formalin fixed, for two years, five weeks, and 12 weeks respectively. The portion of brain from Case 4 was preserved at $-20^{\circ}$ before examination and the three control fresh brains were treated in an identical manner at $-20^{\circ}$.

White matter and cortex were separated and in a portion of each the water content was determined. Lipid extracts were prepared and the lipid content of both white matter and cortex estimated as previously (Cumings and Rozdilsky, 1965) except that total cerebrosides were determined following the techniques of Radin, Brown, and Lavin (1956) and Svennerholm (1956). Thin-layer chromatography (TLC) was performed (Müldner, Wherrett, and Cumings, 1962). On the fresh material plasmalogens were determined by a modification of the two dimensional TLC method of Owens (1966), when the solvent systems used were, firstly, chloroform-methanol-5\% aqueous ammonia (17:7:1 v/v/v) and, secondly, chloroform-methanolwater $(60: 35: 8 \mathrm{v} / \mathrm{v} / \mathrm{v})$.

GAS LIQUID CHROMATOGRAPHY This was performed using a Pye Panchromatograph on a column of $3 \%$ apiezon $\mathbf{L}$ on celite and with a Macro Argon ionization detector. A lipid extract of fresh white matter and cortex of Case 4 was prepared by the method of Folch Lees, and Sloane-Stanley (1957) as for the lipid analysis? and the lipoprotein present denatured with methanol. 음 Cerebrosides and sulphatides were separated from $\frac{5}{5}$ other lipids on 1-cm columns of $3 \mathrm{~g}$ Florosil for every $400 \mathrm{mg}$ wet white matter and $15 \mathrm{~g}$ for every $6 \mathrm{~g}$ weto cortex, employing the method of Kishimoto and Radin ${ }^{\text {S }}$ (1959).

All the cholesterol in the extract was eluted from the column with chloroform $(70 \mathrm{ml}$. for white and $300 \mathrm{ml} . \bar{\omega}$ for cortex), ceramides with chloroform-methanol $19: 1$ ? $\mathrm{v} / \mathrm{v}(10 \mathrm{ml}$. for white and $40 \mathrm{ml}$. for cortex), and cerebroside and sulphatide with chloroform-methanol $2: 1 \mathrm{v} / \mathrm{v}$ ? $(120 \mathrm{ml}$. for white and $300 \mathrm{ml}$. for cortex) (Rouser, Bauman, Kritchevsky, Heller, and O'Brien, 1961). Thee purity of each fraction was determined by TLC.

Cerebroside and sulphatide were separated on DE cellulose as described by Rouser, Kritchevsky, Helle and Lieber (1963) and each column (1 cm wide) contained$2 \mathrm{~g}$ DEAE cellulose for up to every $30 \mathrm{mg}$ cerebroside applied. Cerebroside was eluted from the column wigho $90 \mathrm{ml} .2: 1 \mathrm{v} / \mathrm{v}$ chloroform-methanol, and sulphatide w whe $80 \mathrm{ml}$. chloroform-methanol-concentrated ammonium solution-5M ammonium acetate $(4: 1: 0 \cdot 1: 0.05 \mathrm{v} / \mathrm{v} / \mathrm{v})$ (Menkes, Duncan, and Moossy, 1966) and the purity of 0 each eluate containing either sulphatide or cerebroside determined by TLC. The sulphatide eluate was dried, dissolved in chloroform-methanol $4: 1 \mathrm{v} / \mathrm{v}$, and dialysed for $24 \mathrm{hr}$ against distilled water (O'Brien, Fillerup, ando

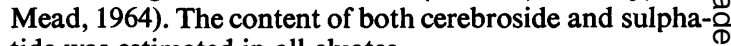
tide was estimated in all eluates.

Hydrolysis was performed according to Hajra and $\vec{F}$ Radin (1962) with $2 \mathrm{ml}$. methanol and $0.4 \mathrm{ml}$. con-응 centrated $\mathrm{HCl}$ and refluxing for 7 to $8 \mathrm{hr}$ under nitrogen in closed tubes. After cooling the fatty acids were extracted three times with $2 \mathrm{ml}$. hexane and methylated:by diazomethane (Baker, 1961).

The hydroxy fatty acid methyl esters were separatedo from the non-hydroxy fatty acid methyl esters on ao column of Florosil (Menkes, Philippart, and Fiol, 1965) The latter were eluted with $30 \mathrm{ml}$. hexane and $20 \mathrm{ml}$. hexane-diethyl ether $(99: 1 \mathrm{v} / \mathrm{v})$ and the former with $50 \mathrm{ml}$. hexane-diethyl ether $(9: 1 \mathrm{v} / \mathrm{v})$. The hydroxy fatty acid methyl esters were acetylated by refluxing $?$ with acetic anhydride for $1 \mathrm{hr}$ in a sand bath, excess of the reagent being evaporated in vacuo at $70^{\circ}$ (Tulloch, 1964). The non-hydroxy and the acetylated hydroxy fatty acid methyl esters were then applied to the panchromatograph, using a temperature programme of $N$ 200 to $230^{\circ}$ for the former and 220 to $240^{\circ}$ for the latter. N 


\section{RESULTS}

Table I shows the analysis of the major lipids in the four cases. The white matter in Case 1 shows a loss of phospholipid but is not otherwise significantly abnormal. The level of cerebroside in the cortex is slightly lower than was previously found in both fresh brain and after two weeks fixation in formalin (Cumings, 1953) but corresponds to the level found after five years' fixation in our experience. It should be emphasized that the level of cerebroside in the white matter does not appear to have been affected by formalin fixation. Levels of cerebrosides have been determined in more than 60 normal brains examined over the past 15 years, both fresh and after one to three months in formalin. The mean figures for fresh white matter and cortex are $11.5 \%$ and $4.1 \%$ and for formalin-fixed tissue $11.2 \%$ and $3.9 \%$. There is a slight loss of cerebroside in the cortex in each of the other three cases. This lowered concentration of cerebroside in the cortex is easily seen in TLC, as shown in Fig. 1 where two separate samples taken from Case 4 are compared with a normal control using equivalent amounts of brain in all lipid samples applied to the plate.

Plasmalogens were estimated in Case 4 and the findings are recorded in Table II together with normal figures.

The results of the analysis of the distribution of fatty acids in cerebroside and sulphatide of Case 4 are given in Tables III and IV, and compared with results of similar examinations made from three adult brains of control subjects. All the results are given as the means of duplicates in the patient and from means of duplicates of all the control brains. The variation between each pair of duplicates was less than $5 \%$.

\section{DISCUSSION}

It is generally agreed that there are areas of a form of demyelination seen microscopically in the brains



FIG. 1. A thin-layer chromatogram of normal cortex and white matter, and of two areas of brain from Case 4, cortex and white matter of each respectively, from left to right. Note reduction of cerebroside (C) particularly in the abnormal cortex. The amount of lipid extract applied represented $4 \mathrm{mg}$ brain tissue in each case.

of phenylketonuric patients (Poser and van Bogaert, 1959; Crome et al., 1962; Gerstl, Malamud, Eng, and Hayman, 1967). These areas are not uniformly distributed throughout the brain and Poser and van Bogaert (1959) considered that the condition belongs to the group which Poser (1961) termed a dysmyelinating disorder. Relatively few biochemical studies have been presented but Crome et al. (1962)

TABLE I

LIPID CONTENT OF BRAINS IN PHENYLKETONURIA

\begin{tabular}{|c|c|c|c|c|c|c|c|c|}
\hline & \multicolumn{2}{|c|}{ Case 1 M.18 } & \multicolumn{2}{|c|}{ Case 2 M.29 (J.M.M.) } & \multicolumn{2}{|c|}{ Case 3 M.I 1 (P.N.) } & \multicolumn{2}{|c|}{ Case 4 M. $18 \frac{1}{2}$ (P.R.S. } \\
\hline & White & Cortex & White & Cortex & White & Cortex & White & Cortex \\
\hline $\begin{array}{l}\text { Total phospholipid } \\
\text { Total cholesterol } \\
\text { Ester cholesterol } \\
\text { Total cerebroside } \\
\text { Total hexosamine } \\
\text { N.A.N.A. }{ }^{1} \\
\text { Water \% }\end{array}$ & $\begin{array}{c}13 \cdot 2 \\
12 \cdot 8 \\
0 \cdot 3 \\
17 \cdot 1 \\
0 \cdot 26 \\
68 \cdot 0\end{array}$ & $\begin{array}{l}9 \cdot 2 \\
6 \cdot 0 \\
0 \cdot 2 \\
5 \cdot 1 \\
0 \cdot 56 \\
0 \cdot 15 \\
82 \cdot 4\end{array}$ & $\begin{array}{r}22 \cdot 2 \\
11.9 \\
1.0 \\
11 \cdot 5 \\
0.3 \\
70.4\end{array}$ & $\begin{array}{l}21 \cdot 0 \\
9 \cdot 4 \\
0 \\
2 \cdot 5 \\
0 \cdot 6 \\
0 \cdot 21 \\
81 \cdot 0\end{array}$ & $\begin{array}{r}21 \cdot 1 \\
10.5 \\
0.7 \\
12.5 \\
0.5 \\
80.5\end{array}$ & $\begin{array}{c}16 \cdot 9 \\
4 \cdot 7 \\
0 \cdot 27 \\
2 \cdot 1 \\
0 \cdot 67 \\
0 \cdot 13 \\
85 \cdot 1\end{array}$ & $\begin{array}{c}27 \cdot 4 \\
14.9 \\
0.9 \\
13.5 \\
0.26 \\
0.06 \\
70.3\end{array}$ & $\begin{array}{c}23 \cdot 0 \\
7 \cdot 2 \\
0 \cdot 8 \\
1 \cdot 8 \\
0 \cdot 65 \\
0 \cdot 31 \\
84 \cdot 3\end{array}$ \\
\hline
\end{tabular}

Results in $\mathrm{g} / 100 \mathrm{~g}$ dry weight.

Brain of Case 4 was fresh and unfixed, the other three had been in formalin.

${ }^{1} \mathrm{~N}$-Acetyl neuraminic acid. 
TABLE II

DISTRIBUTION OF PHOSPHOLIPIDS INCLUDING PLASMALOGENS IN CASE 4

\begin{tabular}{|c|c|c|c|c|c|}
\hline & \multicolumn{2}{|c|}{ Patient } & \multicolumn{2}{|c|}{ Normal } \\
\hline & & White & Cortex & White & Cortex \\
\hline $\begin{array}{l}\text { Total phospholipid g/1 } \\
\text { Ethanolamine } \\
\text { phosphatide } \\
\text { Choline phosphatide } \\
\text { Inositide } \\
\text { phosphatide } \\
\text { Serine phosphatide } \\
\text { Sphingomyelin }\end{array}$ & $\begin{array}{l}\text { as } \% \text { of total } \\
\text { phospholipid } \\
\text { phosphorus }\end{array}$ & $\begin{array}{r}27 \cdot 4 \\
35 \cdot 1 \\
23 \cdot 7 \\
\\
2 \cdot 2 \\
20 \cdot 3 \\
18 \cdot 4\end{array}$ & $\begin{array}{r}23 \cdot 0 \\
35 \cdot 7 \\
38 \cdot 0 \\
2.9 \\
10 \cdot 5 \\
10 \cdot 2\end{array}$ & $\begin{array}{r}25 \cdot 8 \\
36 \cdot 7 \\
24 \cdot 0 \\
2 \cdot 1 \\
18 \cdot 7 \\
17 \cdot 9\end{array}$ & $\begin{array}{r}21 \cdot 8 \\
36 \cdot 2 \\
35 \cdot 4 \\
2 \cdot 7 \\
13 \cdot 1 \\
9 \cdot 4\end{array}$ \\
\hline $\begin{array}{l}\text { Ethanolamine } \\
\text { plasmalogen } \\
\text { Choline plasmalogen } \\
\text { Serine plasmalogen }\end{array}$ & $\begin{array}{l}\text { as molar } \% \text { of } \\
\text { each corres- } \\
\text { ponding } \\
\text { phospholipid }\end{array}$ & $\begin{array}{r}60 \cdot 3 \\
1 \cdot 8 \\
1 \cdot 2\end{array}$ & $\begin{array}{l}34 \cdot 2 \\
-\end{array}$ & $\begin{array}{r}66 \cdot 1 \\
3 \cdot 1 \\
2 \cdot 7\end{array}$ & $\begin{array}{l}43.4 \\
-\end{array}$ \\
\hline
\end{tabular}

found a loss in cerebrosides which was greater than the loss in cholesterol. Foote et al. (1965) found no quantitative abnormalities in cholesterol, cerebroside, or sulphatide, but it is possible that the areas examined were those less affected or even perhaps $\frac{\text { o }}{Z}$ quite unaffected, for it is well known that there is a $\mathbb{D}$ lack of uniformity of the lesions (Poser and van Bogaert, 1959). Menkes (1966) found a reduced $\stackrel{\circ}{\subseteq}$ level of cerebrosides, as is true in three of our four $\stackrel{\equiv}{0}$ cases examined and especially noticeable in Case 4 . 0 Foote et al. (1965) regarded the abnormalities as perhaps related to an arrested development, while Gerstl et al. (1967) discuss a number of possible $\overrightarrow{2}$ aetiological factors, although the evidence for most is slight. It might be stressed that, with an absence $\overrightarrow{\bar{s}}$ of esterified cholesterol, the views of Poser and $\overline{0}$ van Bogaert (1959) and of Foote et al. (1965)- 듬 are strengthened. It is at least possible that the accumulation of abnormal levels of various $\vec{\phi}$ metabolites in the early stages of the disease may affect enzymic processes involved in the laying down of normal myelin in infancy, and thus be $\vec{\circ}$ associated with the loss of cerebrosides found $\vec{\exists}$ biochemically.

Recent studies have been largely concerned with

TABLE III

NON-HYDROXY FATTY ACIDS IN CEROBROSIDES AND SULPHATIDES RESULTS EXPRESSED IN WT PERCENTAGES OF METHYL ESTERS

\begin{tabular}{|c|c|c|c|c|c|c|c|c|}
\hline \multirow{3}{*}{ Fatty acid } & \multicolumn{4}{|c|}{ Cerebroside } & \multicolumn{4}{|c|}{ Sulphatide } \\
\hline & \multicolumn{2}{|c|}{ Phenylketonuria } & \multicolumn{2}{|c|}{ Normal } & \multicolumn{2}{|c|}{ Phenylketonuria } & \multicolumn{2}{|c|}{ Normal } \\
\hline & White & Cortex & White & Cortex & White & Cortex & White & Cortex \\
\hline $\begin{array}{l}16: 1 \\
16: 0 \\
18: 1 \\
18: 0 \\
22: 1 \\
22: 0 \\
23: 1 \\
23: 0 \\
24: 1 \\
24: 0 \\
25: 1 \\
25: 0 \\
26: 1\end{array}$ & $\begin{array}{r}0.3 \\
4 \cdot 2 \\
2 \cdot 7 \\
5 \cdot 8 \\
0 \cdot 4 \\
2 \cdot 5 \\
0 \cdot 8 \\
3 \cdot 7 \\
41 \cdot 4 \\
16 \cdot 4 \\
8 \cdot 7 \\
4 \cdot 8 \\
8 \cdot 2\end{array}$ & $\begin{array}{r}2.0 \\
13.0 \\
14.3 \\
14.4 \\
0.5 \\
2.5 \\
1.0 \\
3.1 \\
24.2 \\
9.2 \\
6.8 \\
3.7 \\
5.1\end{array}$ & $\begin{array}{r}0.4 \\
5 \cdot 0 \\
3 \cdot 3 \\
11 \cdot 1 \\
0 \cdot 6 \\
2 \cdot 5 \\
1 \cdot 1 \\
3 \cdot 2 \\
44 \cdot 4 \\
10 \cdot 0 \\
8.9 \\
2.9 \\
5.9\end{array}$ & $\begin{array}{r}0.9 \\
10.0 \\
8.5 \\
15.7 \\
0.7 \\
2.0 \\
0.7 \\
1.8 \\
30.2 \\
5.3 \\
13.1 \\
4.2 \\
7.1\end{array}$ & $\begin{array}{r}0.2 \\
1.6 \\
1.3 \\
2.3 \\
0.5 \\
2.3 \\
0.7 \\
4.1 \\
36.0 \\
18.6 \\
11.9 \\
7.0 \\
14.0\end{array}$ & $\begin{array}{r}1.3 \\
8.3 \\
7.5 \\
6.2 \\
0.4 \\
2.8 \\
0.7 \\
3.7 \\
36.5 \\
11.9 \\
9.6 \\
5.2 \\
9.0\end{array}$ & $\begin{array}{r}0.2 \\
1.5 \\
1.1 \\
3.0 \\
0.4 \\
1.9 \\
1.0 \\
3.3 \\
49.6 \\
12.2 \\
11.6 \\
7.6 \\
9.4\end{array}$ & $\begin{array}{r}1 \cdot 1 \\
7 \cdot 3 \\
4 \cdot 2 \\
6 \cdot 6 \\
0 \cdot 6 \\
2.9 \\
0 \cdot 7 \\
2 \cdot 8 \\
39 \cdot 8 \\
10 \cdot 0 \\
12 \cdot 4 \\
3 \cdot 8 \\
7 \cdot 2\end{array}$ \\
\hline
\end{tabular}

All in duplicate; normals means of three brains.

TABLE IV

HYDROXY FATTY ACIDS IN CEREBROSIDES AND SULPHATIDES RESULTS EXPRESSED AS WT PERCENTAGES OF ACETOXY AND METHYL ESTERS

\begin{tabular}{|c|c|c|c|c|c|c|c|c|}
\hline \multirow{3}{*}{ Fatty acid } & \multicolumn{4}{|c|}{ Cerebroside } & \multicolumn{4}{|c|}{ Sulphatide } \\
\hline & \multicolumn{2}{|c|}{ Phenylketonuria (I) } & \multicolumn{2}{|c|}{ Normal (3) } & \multicolumn{2}{|c|}{ Phenylketonuria (I) } & \multicolumn{2}{|c|}{ Normal (3) } \\
\hline & White & Cortex & White & Cortex & White & Cortex & White & Cortex \\
\hline $\begin{array}{l}22: 0 \\
23: 0 \\
24: 1 \\
24: 0 \\
25: 1 \\
25: 0 \\
26: 1\end{array}$ & $\begin{array}{r}8.9 \\
16.5 \\
20.2 \\
42.5 \\
1.9 \\
6.5 \\
3.7\end{array}$ & $\begin{array}{r}7 \cdot 2 \\
17 \cdot 7 \\
17 \cdot 9 \\
46 \cdot 1 \\
3 \cdot 0 \\
6 \cdot 5 \\
4 \cdot 3\end{array}$ & $\begin{array}{r}8 \cdot 2 \\
16 \cdot 5 \\
26 \cdot 9 \\
36 \cdot 6 \\
4 \cdot 2 \\
5 \cdot 2 \\
3 \cdot 6\end{array}$ & $\begin{array}{r}7 \cdot 8 \\
14 \cdot 1 \\
23 \cdot 8 \\
37 \cdot 1 \\
4 \cdot 2 \\
5 \cdot 8 \\
6 \cdot 5\end{array}$ & $\begin{array}{r}5 \cdot 2 \\
12 \cdot 8 \\
15 \cdot 0 \\
50 \cdot 2 \\
2.4 \\
7 \cdot 9 \\
6.6\end{array}$ & $\begin{array}{r}9 \cdot 2 \\
12.6 \\
17 \cdot 6 \\
38 \cdot 0 \\
4 \cdot 1 \\
8 \cdot 5 \\
9 \cdot 7\end{array}$ & $\begin{array}{r}6 \cdot 0 \\
13 \cdot 7 \\
21 \cdot 8 \\
40.3 \\
3 \cdot 3 \\
8 \cdot 3 \\
6.2\end{array}$ & $\begin{array}{r}7 \cdot 4 \\
11 \cdot 8 \\
26 \cdot 3 \\
34 \cdot 9 \\
7 \cdot 8 \\
7 \cdot 4 \\
4 \cdot 4\end{array}$ \\
\hline
\end{tabular}

All results in means of duplicate.

Figures in parentheses indicate number of brains examined. 
the distribution of fatty acid in some lipids of the brain. Gerstl et al. (1967), who estimated the unsubstituted and the 2-hydroxy fatty acids in whole white matter, showed a loss of mono- and polyunsaturated acids in the extensively damaged areas. They suggest that there may be a disturbance in the build-up of long chain fatty acids from the shorter chain fatty acids. Menkes as well as Foote et al. (1965) have studied, as we have, both the hydroxy and the non-hydroxy fatty acids in cerebrosides and sulphatides. All three groups of workers have found a slight reduction in $24: 1$ nonhydroxy acids in both these lipids with only minor variations from the normal in the hydroxy fatty acids. Menkes (1966) in one case found only a branched chain fatty acid ( $\mathrm{BrA}$ ) forming $63.1 \%$ of the total fatty acids, but no other worker has obtained a similar finding. Our results reported here closely follow those of Foote et al. (1965) except that $24: 0$ was raised at the same time as $24: 1$ was reduced. This was also true in the cerebral cortex in our case as far as the non-hydroxy fatty acid in cerebroside was concerned. The hydroxy acids also showed a slight reduction of $24: 1$ and an increase of $24: 0$ in the cerebroside and sulphatide in the white matter. It should be mentioned that all values of $24: 1$ and $24: 0$ obtained in the pathological material were outside the range of all the three normals.

There is as yet insufficient evidence to indicate the aetiology of the demyelination or of the abnormality in fatty acid composition and further most of the material examined thus far has been from patients who have survived for some years. It is perhaps of some interest that, together with this loss of cerebroside and altered fatty acid pattern, there was a slightly decreased level of ethanolamine plasmalogen as compared with figures obtained from normal cerebral tissue in both the white matter and the cortex-even though the total concentration of ethanolamine did not differ from our normal range obtained from over 25 brains. This aspect requires further study in the brains of patients with a shorter survival time.

\section{SUMMARY}

The lipid composition of four brains from patients with phenylketonuria has been studied and a slight loss of cerebroside in three cases shown together with decreased levels of ethanolamine plasmalogen in one case.

Fatty acid analysis of cerebroside and sulphatide has shown a reduction of $24: 1$ and a slight increase of $24: 0$ acids.

These results are discussed in relation to other reported findings.

Our thanks are due to Dr. C. M. Poser, Dr. L. Crome, and Dr. M. Erdohazi for the material. T.Y. was a Special Research Fellow, Mayo Foundation, Rochester, Minnesota, and I.K.G. a British Council Scholar.

\section{REFERENCES}

Baker, R. W. R. (1961). Ester-linked long chain fatty acids of nervous tissue. Biochem. J., 79, 642-648.

Crome, L., Tymms, V., and Woolf, L. I. (1962). A chemical investigation of the defects of myelination in phenylketonuria. J. Neurol. Neurosurg. Psychict., 25, 143-148.

Cumings, J. N. (1953). The cerebral lipids in disseminated sclerosis and in amaurotic family idiocy. Brain, 76, 551-562.

- and Rozdilsky, B. (1965). The cerebral lipid composition of the brain in six cases of Krabbe's disease. Neurology (Minneap.), 15, 177-183.

Folch, J., Lees, M., and Sloane-Stanley, G. H. (1957). A simple method for the isolation and purification of total lipids from animal tissues. J. biol. Chem., 226, 497-509.

Foote, J. L., Allen, R. J., and Agranoff, B. W. (1965). Fatty acids in esters and cerebrosides of human brain in phenylketonuria. J. Lipid Res., 6, 518-524.

Gerstl, B., Malamud, N., Eng, L. F., and Hayman, R. B. (1967) Lipid alterations in human brains in phenylketonuria. Neurology (Minneap.), 17, 51-57.

Hajra, A. K., and Radin, N. S. (1962). Biosynthesis of the cerebroside odd-numbered fatty acids. J. Lipid Res., 3, 327-332.

Kishimoto, Y., and Radin, N. S. (1959). Isolation and determination methods for brain cerebrosides, hydroxy fatty acids and unsaturated and saturated fatty acids. J. Lipid Res., 1, 72-78.

Menkes, J. H. (1966). Cerebral lipids in phenylketonuria. Pediatrics, 37, 967-978.

- Duncan, C., and Moossy, J. (1966). Molecular composition of the major glycolipids in globoid cell leukodystrophy. Neurology (Minneap.), 16, 581-593.

- Philippart, M., and Fiol, R. E. (1965). Cerebral lipids in maple syrup disease. J. Pediat., 66, 584-594.

Müldner, H. G., Wherrett, J. R., and Cumings, J. N. (1962). Some applications of thin-layer chromatography in the study of cerebral lipids. J. Neurochem., 9, 607-611.

O'Brien, J. S., Fillerup, D. L., and Mead, J. F. (1964). Brain lipids: 1. Quantification and fatty acid composition of cerebroside sulfate in human cerebral grey and white matter. J. Lipid Res., 5, 109-116.

Owens, K. (1966). A two-dimensional thin-layer chromatographic procedure for the estimation of plasmalogens. Biochem. J., 100, 354-361.

Poser, C. M. (1961). Leukodystrophy and the concept of dysmyelination. Arch. Neurol. (Chic.), 4, 323-332.

phenylketonuria. Brain, 82, 1-9.

Radin, N. S., Brown, J. R., and Lavin, F. B. (1956). The preparative isolation of cerebrosides. J. biol. Chem., 219, 977-983.

Rouser, G., Bauman, A. J., Kritchevsky, G., Heller, D., and O'Brien, J. S. (1961). Quantitative chromatograph fractionation of complex lipid mixtures: brain lipids. J. Amer. Oil Chem. Soc., 38, 544-555.

_, Kritchevsky, G., Heller, D., and Lieber, E. (1963). Lipid composition of beef brain, beef liver and the sea anemone. Two approaches to quantitative fractionation of complex lipid mixtures. J. Amer. Oil. Chem. Soc., 40, 425-454.

Svennerholm, L. (1956). The quantitative estimation of cerebrosides in nervous tissue. $J$. Neurochem., 1, 42-53.

Tulloch, A. P. (1964). Gas liquid chromatography of the hydroxy, acetoxy- and the oxo-stearic acid methyl esters. J. Amer. Oil Chem. Soc., 41, 833-836. 